\title{
Cuba 2017: The End of AN ErA
}

Cuba 2017: el fin de una era

\section{TERESA GARCÍA CASTRO}

Washington Office on Latin America, USA

\section{PHILIP BRENNER}

American University, USA

\begin{abstract}
In 2017, Cuba prepared itself for a momentous change that was coming in 2018: the first time in 59 years that a Castro would not be leading the government. No one expects Miguel Díaz-Canel Bermúdez, whom the National Assembly elected as Cuba's president in April 2018, to chart a course dramatically different from the one President Raúl Castro had established. However, given the economic, demographic, and international political challenges Cuba faced in 2017, the year had to be viewed as the end of an era. Change is inevitable in order to sustain the Cuban Revolution.
\end{abstract}

Keywords: Cuba, Castro, Díaz-Canel, U.S.-Cuba, elections

\section{RESUMEN}

En 2017, Cuba se preparó para un cambio trascendental que venía en 2018: la primera vez en 59 años que un Castro no lideraría el gobierno. Nadie espera que Miguel Díaz-Canel Bermúdez, a quien la Asamblea Nacional eligió como presidente de Cuba en abril de 2018, trace una ruta radicalmente diferente a la que había establecido el presidente Raúl Castro. Pero dados los desafíos económicos, demográficos e internacionales que enfrentó Cuba en 2017 , el año tiene que ser visto como el final de una era. El cambio es inevitable para sostener la Revolución Cubana.

Palabras clave: Cuba, Castro, Díaz-Canel, Estados Unidos-Cuba, elecciones 


\section{INTRODUCTION}

A visitor to Cuba at the beginning of 2018 would have experienced a far different country than when Raúl Castro became president ten years earlier-more open, vibrant, and bustling. While some Cubans complained that they were only running in place, that many changes they wanted had not materialized, in fact Cuba's economy, politics, and social organization already had begun a historic transformation as the country prepared for new political leadership in 2018.

There was no evidence that anyone expected Miguel Díaz-Canel Bermúdez, whom the National Assembly elected as Cuba's president on 19 April 2018, to chart a course that departed dramatically from the one President Castro had established. Moreover, the Cuban leadership and much of the population seemed to share a consensus that Cuba should continue its revolutionary commitment to the promotion of economic development with equity, its centuries-old quest to keep Cuba independent from the dominance of a single foreign power, and its sixty-year embrace of the ideals of South-South solidarity.

Yet given the economic, demographic, and international political challenges that Cuba faced in 2017, the year had to be viewed as the end of an era. President Castro undoubtedly would have liked the country to have gone farther on many fronts by the end of 2017. He acknowledged in mid-2016 that the Cuban economy was suffering severe problems and warned that it would be "imperative to reduce expenses of all kinds that are not indispensable, to promote a culture of conservation and the efficient use of resources available" (R. Castro Ruz 2016). Similarly, the 2016 Cuban Communist Party Congress reported that only twenty-one percent of the reforms intended to "update" the Cuban economic model had been fulfilled completely (Communist Party of Cuba 2016). In addition, U.S. President Donald Trump undercut improved relations with the United States, which has been set in motion in 2014, and the resulting tension strengthened the hands of Cuban officials who opposed greater openness internally. With only limited changes being implemented in 2016 and 2017, it seemed inevitable that the new Cuban president would initiate more meaningful change in order to sustain the Cuban Revolution.

\section{MOVING FROM THE PAST}

In 1990, with the Soviet Union beginning to collapse and the Council for Mutual Economic Assistance (CMEA) set to disband, Fidel Castro announced that Cuba would be entering a "special period in a time of peace," which he said meant that "our country has to face an extremely difficult situation in supplying basic necessities" (F. Castro Ruz 1990). Eighty-five percent of Cuba's international commerce had been conducted with CMEA countries on the basis of long-term barter-like contracts. The terms of trade in these exchanges, especially with the Soviet Union, tended to function like subsidies that favored Cuba. As the 
country's Gross Domestic Product declined by thirty percent over the next three years, diseases resulting from malnutrition such as neuropathy began to emerge, tens of thousands of Cubans attempted to flee the island on rafts, and petty crime began to flourish. Cuban leaders responded by experimenting with a variety of market techniques to alleviate the suffering. These included the legalization of small private restaurants (paladares) and the use of U.S. dollars for the purchase of goods and services. Foreign corporations also gained increased opportunities to invest in commercial ventures, especially the previously neglected tourist sector which became a major source of hard currency earnings. When the government opened stores that sold scarce commodities that Cubans could purchase only with hard currency, it created a dual currency economy.

Cubans who had access to hard currency generally were those with relatives who sent remittances from abroad or those with jobs in the newly emerging tourist sector that enabled them to earn hard currency from gratuities. The resulting uneven distribution of hard currency undermined the Cuban Revolution's proud achievement of broad economic, social, and racial equality (Espina Prieto 2004: 219-225). Before the 1990s, the highest paid Cubans were those with advanced degrees - doctors and engineers - who provided essential services for the country. Yet they earned only four to five times more than the lowest paid workers. The dual currency system introduced distortions in the incentive system that undermined Cuba's ability to sustain a large pool of educated workers. A taxi driver with only a high school education could earn as much in one day as a doctor earns in one month (Harris 2015; Hansing 2017: 335).

The widening inequality in the population was evidently a major reason Fidel Castro reversed the process of privatization once the economy started to rebound. He charged in 1995 that corruption was undermining a culture of shared sacrifice and that foreign investment was the root cause of corruption. Notably, the number of government-issued licenses for self-employed businesses reached its peak in 1996 and declined afterwards. Yet the more likely sources of inequality were the continuing scarcity of necessities, the dual currency economy, and Cuba's reliance on remittances and tourism for hard currency. With infusions of capital from foreign investors, hotel capacity steadily increased after the mid1990s, and gross revenue from tourism surpassed that from sugar. The number of tourists hit the two million mark in 2003 and went beyond four million in 2016 (Brenner and Eisner 2018: 232).

Meanwhile, Cuba continued to play a role in Latin American affairs that was out of proportion to its size, even without Fidel Castro as its leader. (Raúl Castro became interim president on 31 July 2006, when illness forced Fidel Castro from power. In 2008, the National Assembly formally elected the youngest Castro as Cuba's president, and re-elected him in 2013.) Cuba's international influence in the first decade of the twenty-first century was due in part to its close association with Venezuela. In 2008, oil sold for nearly double the price it had in 2017, and Venezuela offered reduced oil prices as a way to purchase influence and good will that spilled over to Cuba. 
In addition, Latin American countries filled a vacuum created by a languishing Organization of American States (OAS) to create regional institutions for hemispheric cooperation. The most prominent was the Community of Latin American and Caribbean Countries (CELAC), whose members include every country in the Western Hemisphere except the United States and Canada. Formed in 2010, the organization held its 2013 summit in Havana, because the members had chosen Cuba to be the co-chair. Their choice was a not-too-subtle message to Washington, which had prevented Cuba from participating in a 2012 OASled hemispheric summit. Just prior to the 2013 conclave, the European Union announced that CELAC, not the OAS, would be its counterpart organization for bi-regional negotiations, significantly increasing CELAC's importance.

Also meeting in Havana were negotiators from the Colombian government and the Revolutionary Armed Forces of Colombia (FARC), the main insurgent group in the country. The peace negotiations began in mid-November 2012. Colombia was the third largest recipient of U.S. economic and military aid in the world - an average of more than $\$ 700$ million per year for over two decades. Yet Colombian President Juan Manuel Santos was willing to issue a stark ultimatum in April 2012 on behalf of the other heads of state attending the OAS Summit of the Americas, that there would be no 2015 summit unless Cuba were permitted to participate. Shortly afterward, President Obama fired his national security adviser for Latin America. He then agreed to negotiations between Cuba and the United States that led to the restoration of diplomatic relations in 2015.

Raúl Castro did not share his brother's deep disdain for markets and privatization. He had been an advocate in 1993 for legalizing the use of the U.S. dollar in domestic commerce and for creating semi-private enterprises in which military officers were able to find jobs when he downsized the Cuban armed forces by fifty percent. For this reason, there was a widespread expectation, or perhaps hope, that he would initiate major economic change. Instead, he moved cautiously during his first year as Cuba's elected president. In 2008, Cubans were permitted to buy mobile phones and stay at hotels built for foreign tourists, and in 2009 they gained some access to the internet. In March 2009, President Castro replaced several key ministers, most notably removing Foreign Minister Felipe Pérez Roque and Carlos Lage Dávila, secretary of the Council of Ministers and the Vice President in charge of the Cuban economy. Both had been close to Fidel Castro and analysts often described them as likely leaders among the generation that would take over when the históricos retired. Then, in April 2010, President Castro shocked the country by announcing a plan to reduce the state's workforce by one million employees - a cut of nearly twenty percent. "We must erase forever the notion that Cuba is the only country in the world where one can live without working," he told the National Assembly in August 2010 (R. Castro Ruz 2010).

The pace of change began to accelerate after April 2011 when the Cuban Communist Party's Congress approved a major new program, "Guidelines for the Economic and Social Policies of the Party and the Revolution," 
known as Lineamientos. In effect, Cuba's leaders acknowledged that economic development would require them to place efficiency and macroeconomic growth ahead of values such as egalitarianism, and that this reorientation would require a greater reliance on market considerations in determining wages and even what enterprises produced. Once the government began to implement the Lineamientos, the nonstate sector (cooperatives and the self-employed) of the economy soared. By 2016, it had grown to its largest size since the early 1960s, accounting for nearly thirty percent of total official employment (Torres Perez 2017: 262-263). The number of authorized self-employed rose from about 150,000 in 2008 to 580,000 in 2017, and authorities had approved 439 non-farm cooperatives (Feinberg 2018: 14; ONEI 2018: 2). The Lineamientos continued to serve as the principal framework for "updating" the Cuban economic model, which is how the government characterizes the process of restructuring.

\section{RESTRUCTURING THE CUBAN ECONOMIC MODEL}

In 2016, the economy experienced two consecutive quarters of negative growth-i.e., a recession-for the first time in nearly a quarter-century (Frank 2017a). The tourism sector was the only leading export with robust performance and continues to be one of the pillars of Cuba's economy. Tourism arrivals more than doubled during the decade of Raúl Castro's rule, jumping from 2.2 million in 2006 to an estimated 4.7 million in 2017 (Feinberg 2018: 6). The total included 619,000 U.S. travelers, an increase of 18\% over 2016 (Jervis 2018).

Figure 1. Pattern of Cuba's Macro-Economic Performance

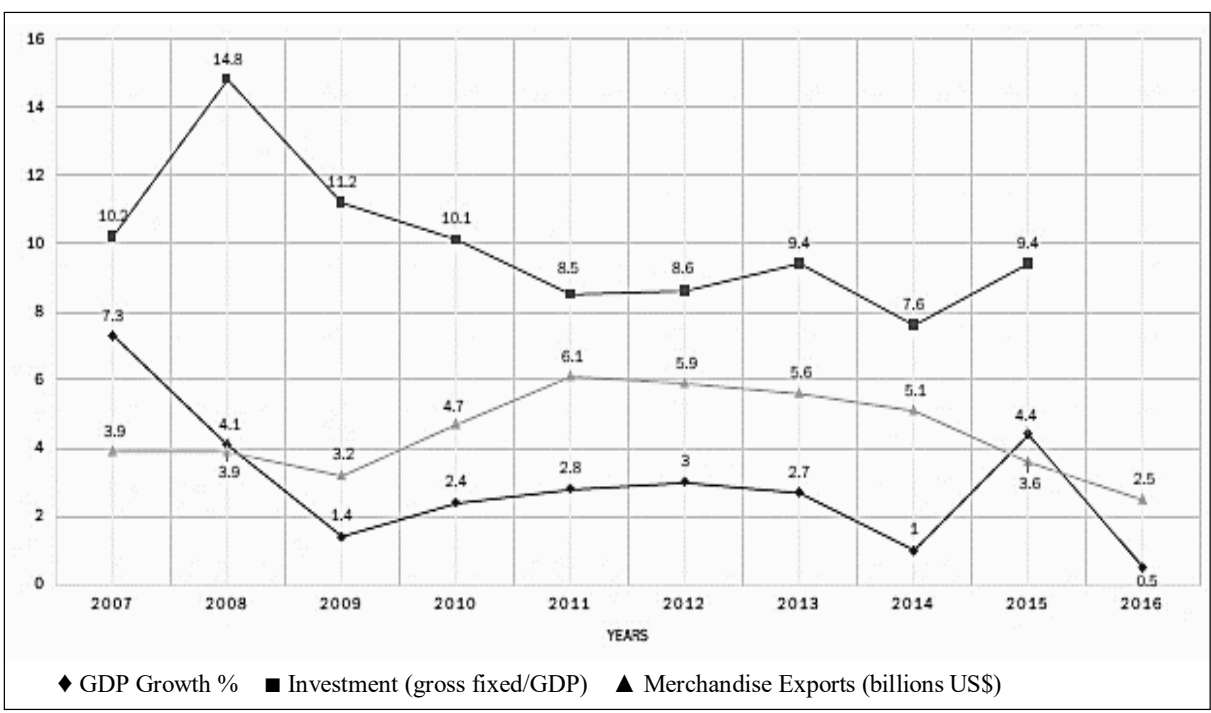

Source: https://www.brookings.edu/wp-content/uploads/2018/02/fp_20180220_cuba_economy.pdf 
The majority of Cuban commodity exports (nickel, tobacco, and sugar) faced important supply constraints and weak prices in their international markets in 2017. The country's petroleum exports suffered the combined impacts of a declining Venezuelan supply and collapsing hydrocarbon prices. The export of Cuban healthcare services remained concentrated in Venezuela and Brazil, two nations which themselves were suffering an economic downturn. Venezuela's problems, in particular, negatively affected Cuba's economy, as the resulting higher petroleum costs led the Cuban government to restrict the use of fuel and electricity.

Hurricane Irma, which left ten dead, also severely damaged the economy. The strongest storm Cuba had encountered in 85 years, Irma reduced Cuba's sugar production and affected tourist facilities. It damaged 300,000 hectares of sugarcane crops and forty percent of Cuba's sugar refineries (Granma 2017c). It also destroyed most structures on Cuba's keys and all but wiped out the Jardines del Rey international airport in Cayo Coco.

Another obstacle that prevented further growth in 2017 included the government's failure to create promised wholesale markets at which small businesses could buy food, tools, and business necessities. (The first wholesale market finally opened in March 2018.) In addition, cumbersome rules blocked the development of cooperatives. While a municipal agency is able to approve a license for a cuentapropista (an individual private business), only the Council of Ministers that can authorize the operation of a non-agricultural cooperative.

Government initiatives that did contribute to the growth of the small business sector between 2011 and 2016 included the relaxation of some restriction on private operations. For example, new rules permitted paladares to hire nonfamily members and seat more than twelve diners at one time. In 2011, the government legalized the sale of homes and vehicles, which provided a new way for Cubans to acquire and create income and wealth. The liberalization of travel in 2013 - allowing citizens to live outside of the country for up to two years without losing citizenship or property rights-enabled Cubans to acquire professional experience, earn good wages, and bring home both improved skills and hard currency.

In June 2017, the National Assembly passed a resolution approving a statement of principles and strategic objectives for Cuba's socialist system (Granma 2017a). The statement reaffirmed the socialist state-run enterprise as the basis for national development, but explicitly added a new non-state element, private enterprise. However, it does not envision that privatization would include Cuba's infrastructure or its major state-owned assets such as nickel, petroleum. and advanced technology industries.

Yet officials let another year pass without implementing a promised and necessary move, the unification of the currency. Cuba replaced the US dollar 
in 2004 with a monetary instrument it calls the Cuban Convertible Currency (CUC), which is the only hard currency that can be used legally. A CUC can be purchased internally at the official exchange rates of US\$1.00 for 1 CUC or 24 Cuban pesos (CUP) for one CUC. However, for transactions with international companies, Cuba has set the exchange rate at US\$1.00 for 1 CUP. As a result, state firms cannot accurately determine their actual profit and loss posture, or how to price a product that includes foreign and domestic components. The dual currency system makes exports less competitive and discourages import substitution (Monreal Gonzalez 2017). It also repels foreign investors who need to rely on a consistent monetary instrument. Foreign investors decry, as well, their inability to pay Cuban workers directly. The government collects the hard currency salaries from a company and pays the workers in Cuban pesos at the one-to-one exchange rate. Thus, when a firm nominally pays a worker $400 \mathrm{CUC}$ per month, the worker receives only 400 CUP.

These obstacles begin to explain why foreign direct investment (FDI) has been less robust and concentrated in fewer kinds of economic activities than Cuban leaders had projected. Forty percent of FDI has been directed to the tourism sector, with far less investment in nickel, agribusiness (mainly citrus), construction, communication, and transportation. Consider the muchtouted Special Economic Opportunity Zone of Mariel, located about forty-five kilometers west of Havana. It consists of a new world-class port that can dock the super-Panamax container ships from the enlarged Panama Canal, the Mariel Special Development Zone (ZEDM) which covers 466 square kilometers, and a new rail connection to Havana. Construction of the port facility, which cost nearly $\$ 1$ billion, was a joint venture with Odebrecht, the Brazilian engineering conglomerate; the port is managed by PSA International, a Singapore firm. While the government did ease some restrictions on investments in the ZEDM so that it could almost serve as an export processing zone, fewer than a dozen foreign investors signed agreements for the ZEDM in its first four years ending in 2016. Even Odebrecht held off until February 2016.

Making Cuba more attractive to foreign investors has been a key goal of the economic reform program planners. A 2014 FDI law offers terms that are regionally competitive. Cuban leaders are actively courting foreign investors, and each year the government publishes a portfolio of priority investment opportunities. However, as economist Ricardo Torres notes, the targets of foreign capital inflows (between $\$ 2.0$ billion and $\$ 2.5$ billion per annum) and the priority injection of FDI in export-generating sectors had fallen quite below expectations (Torres Perez 2017: 265). Officials did claim that in 2017 Cuba signed thirty agreements attracting US\$2 billion in FDI (Reuters 2017).

To face some of these economic challenges, Cuba has tried to diversify its trade partners. China replaced Venezuela as Cuba's top trading partner in 2016, when total trade between the two countries reached US\$2.6 billion, more than $60 \%$ above the annual average of the previous decade (ONEI 2017b). Beyond investments in nickel and oil production, China produces Yutong buses and 
YTO tractors, and even invested US\$500 million in a golf resort. During his 2016 trip to the island, Chinese Premier Li Keqiang signed approximately thirty economic cooperation agreements covering science, environmental protection, energy, public health, agriculture, and the extension of credit for some projects.

Meanwhile, as supplies from Venezuela declined in 2017, Cuba imported 2.1 million barrels of oil from Algeria in 2017 (Reuters 2018). The European Union also announced it would contribute 18 million euros ( US\$22.4 million) over five years in a program that marks the bloc's first financing to the island since the EU-Cuba bilateral cooperation agreement came into force in 2017. EU financing will focus on Cuba's US\$4 billion renewable energy expansion plan which has the goal of generating 24 per cent of the island's electricity from renewable sources by 2030 .

Repaying its debts was a key hurdle Cuba had to overcome in order to access international capital markets and to attract large-scale foreign investment. In 2015, it reached a debt-restructuring agreement with the Paris Club, a group of major creditor nations. Two years later, Cuba paid creditors $\$ 2.6$ billion, the second installment on its renegotiated debt (Frank 2017b).

The country also found new sources of capital. In 2016, the Development Bank of Latin America (known as CAF) signed its first collaboration agreement with Cuba, designed to foster technical cooperation in socio-economic development projects on the island, and to further regional integration (Radio Rebelde 2016). In addition, Cuba became a member of the Central American Bank for Economic Integration (CABEI) in 2017 and signed an agreement that featured development projects for the region (Granma 2017b).

\section{DEBATING POLITICAL CHANGES, ELECTIONS AND LEADERSHIP}

Cuba experienced little formal political change in 2017 as all eyes focused on the impending transfer of presidential power to First Vice President Díaz-Canel and a new generation of leaders. The process of electing the president began at the local level in November 2017. Local electoral commissions drew up lists of candidates for each of the 605 districts from which Cubans elect deputies to Cuba's parliament, the National Assembly. Half of the deputies were drawn from the six Cuban mass organizations: Cuban Workers' Federation, Committees for the Defense of the Revolution, Federation of Cuban Women, Federation of University Students, Federation of Secondary School Students, and the National Association of Small Farmers. The other half was made up of delegates who had been elected to local municipal councils. 


\section{Chart 2: Cuban Government Organizational Structure}

Legislative Bodies

National Assembly

605 delegates directly elected from equally proportioned districts

Headed by the president of the

National Assembly

Establishes all national laws

Council of State

31 members

Serves as executive committee of National Assembly, acting in its place when the National

Assembly is out of session

Headed by President of Cuba

\section{Provincial Assemblies}

Legislative body for each province

Delegates directly elected by districts

Responsible for overseeing provincial administration

\section{Municipal Assemblies \\ Oversees functioning of municipal administration \\ One delegate elected from each district}

\section{Popular Councils}

Supports the municipal assembly in the exercise of its powers and facilitates better understanding and addressing the needs and interests of the inhabitants of its area of action

\section{Executive Bodies}

Council of Ministers

33 members

Highest administrative and executive body of government

Coordinates/directs execution of political, economic, cultural, social, scientific, and defense policies

Members: President (chief of state), Vice Presidents, and heads of government ministries; may include others designated by law

\section{Provincial Administration}

Carries out provincial level management functions

Responsible to provincial assembly

\section{Municipal Administration}

Carries out management functions at local level

Responsible to municipal assembly

Expected to be given more authority in future as national government attempts to decentralize decision-making
Judicial Bodies

People's Supreme Court

Nominally independent

Elected by and accountable to the

National Assembly

Appeals Courts

Seven regional

courts

National Assembly elects judges

\section{Peoples Courts}

Municipal assemblies elect judges

Implement decisions from Supreme Court

\section{District Courts}

Adjudicate civil and criminal cases

In March 2018, 83\% of the electorate turned out to elect 605 deputies to the National Assembly and 1265 delegates to Cuba's provincial assemblies. The process ended on 19 April 2018, when the National Assembly elected the new President, first Vice President, and Council of State.

President Díaz-Canel turned 58 the day after he was elected president. As someone who grew up in the Cuban Revolution, his formative experiences were quite different from the revolutionary generation that governed Cuba until now. His rise to power also reflects Raúl Castro's commitment to a more 
institutionally-bound decision-making process, and to promoting people based on experience and merit. Trained as a civil engineer, Díaz-Canel served a short time in the military beyond his compulsory service and rose to prominence as the First Secretary of the Communist Party in the provinces of Villa Clara and Holguin. When he was selected to join the Communist Party's Political Bureau in 2003, he became the youngest person named to the party's highest body. Prior to becoming First Vice President in 2013, he was Minister of Higher Education.

The composition of the National Assembly of People's Power and well as the Vice Presidents of the Council of State, 6 in total, reflect more diversity and reflect generational changes. A total of $58 \%$ of the deputies in the newly constituted National Assembly were elected for the first time. Almost half (48.4\%) of the elected deputies are women and $41 \%$ are Afro-Cuban. The average age is 49 , and 80 deputies are between 18 and 35 years old. On the other hand, half of the Vice Presidents are women, half are black, and the three new Vice Presidents range in age from 48 to 52. Notably, only one of them, Ramiro Valdes, was a former member of the military, while the professional backgrounds of the rest include a workers' leaders, engineers, the General Comptroller and the Minister of Health Care (Granma 2018).

Formally, the president of the country is the President of the Council of State, which serves as the executive committee of the Assembly. All of the Council's members are elected deputies in the National Assembly, which meets only twice each year in short sessions. When it is not in session, the Council of State issues decrees on its behalf. There is also a President of the National Assembly. The Council of Ministers, with twenty-two members, leads the executive branch and is chaired by the country's President. While the Council makes formal decisions, the essential decision-making authority lies with its nine-member executive committee, which includes the First Vice President and four other Vice Presidents.

Laid over this governmental structure is the Cuban Communist Party (PCC), which is intended to serve as a kind of board of directors and political guide for the government. High officials in the executive and legislative branches are also leaders in the PCC. The Party Congress, which meets once in five years, nominally governs the PCC. Its most recent meeting occurred in April 2016, when nearly 1,200 delegates participated. The Congress elects both the Central Committee (currently it has 142 members) and the First Secretary of the PCC. Raúl Castro, like his brother, served as President of the Councils of State and Ministers and First Secretary of the PCC. He was re-elected as the First Secretary in 2016 and will continue in this post until 2021. This is the first time since the founding of the PCC in 1965 that the President of Cuba and the First Secretary of the PCC are different people, and it remains uncertain how the relationship between them will evolve. However, during his eleven years as president, Raúl Castro attempted to create clear lines of accountability in government decision-making, which meant reducing the role of the PCC in the details of policy making. In 2012, for example, he declared that the Communist 
Party had neglected its political responsibilities by becoming too involved in state administration. The PCC, he said, "provides leadership by supervising and this term must be understood as confirming, examining, reviewing, never intervening or giving orders" (Castro Ruz 2012).

After 2006, when Raúl Castro became the interim president, he repeated the theme that the future of the Cuban Revolution would depend on open discussion and disagreement. Speaking to Cuba's Federation of University Students in 2006, he asserted, "sometimes people fear the word disagree, but I say the more debate and the more disagreement you have, the better the decisions will be" (Boadle 2006). In 2012, he denounced "false unanimity" and declared, "We need to accustom ourselves to expressing truths face to face, looking each other straight in the eye, to disagree and argue, to even disagree with what leaders say, when we believe that we are in the right" (Castro Ruz 2012). Prior to the 2011 PCC Congress, the government encouraged active debate about the Lineamientos. At the time, "there were calls for a change of mentality among leaders and administrators...to listen to the population," economist Jorge Mario Sanchez has noted, and "the press began to publish letters and articles exposing wrong or arbitrary decisions in state enterprises and ministries to public scrutiny" (Sánchez Egozcue 2014: 125).

The economic problems Cubans experienced in the 1990s also engendered debate, because old certainties-about the historical inevitability of socialism outlasting capitalism and about the viability of the Soviet model-fell to the wayside. Yet tacit assent from the top leadership accompanied by its tolerance of critical views in publications, the arts, and more recently in the blogosphere, as well as the decision to provide greater access to the internet, were the main drivers in providing Cubans with an unprecedented and readily available diversity of viewpoints.

Political sociologist Rafael Hernández argues that increased access to digital media has also accelerated the transformation of Cuba's civil culture, including mass cultural consumption and production (Hernández 2017: 415). There has been a revival of periodicals and public spaces for debate on topics as diverse as the nature of socialist democracy, human rights, citizen participation, violence, local initiatives, urban and community problems, religious faiths, and gender. In February 2018, Cuba Posible published an interactive media map that illustrates the variety and breadth of "spaces" that exist in Cuba for blogs, magazines, and journals. It registered a total of 209 media fora and found that every Cuban province had at least a few (Cuba Posible 2018).

Between 2011 and 2016, the percentage of Cuban individuals using the internet more than doubled, to $37.31 \%$ (International Telecommunications Union 2017). Two social media management platforms- "We Are Social" and "Hootsuite" named Cuba as the biggest social media growth story for 2017, as users jumped $368 \%$ (Kemp 2017). In addition to cyber platforms, digital information is widely disseminated across the island through the paquete semanal (Weekly Package), 
a nonstate digital data distribution system. The paquete gathers thousands of hours of material from sources worldwide-mostly in violation of international copyright-from broadcast networks, distributors such as Netflix and Hulu, video game purveyors, and news and sports outlets. It then sells particular programs, entire seasons, or films to individuals who download them to a portable medium such as a USB drive (García Martínez 2017). Television shows that were available during the week of 9 April 2018, for example, included "The Americans," "Homeland," "Madam Secretary," "Atlanta," "NCIS," and "Empire" (El Paquette 2018).

The Cuban Ministry of Culture and the Cuban Roman Catholic Archdiocese have also played a role in creating space for free expression and open dialogue. Temas magazine, for example, was protected initially by Abel Prieto Jiménez, a journalist and novelist who became Minister of Culture in 1997. By including topics rarely covered in the official media and articles which often express views well outside the mainstream, the magazine helped to expand the borders of what was acceptable. By 2012, when Prieto stepped down as minister, the magazine had acquired widespread support among officials, and it had expanded its production to include a television program and blogs.

As a prelude to Pope John Paul II's visit Cuba in 1998, in 1992 the Cuban government began allowing the Church to disseminate its publications to a larger audience than before. Cardinal Jaime Ortega y Alamino, the Archbishop of Havana, used this opportunity to create Palabra Nueva and Espacio Laical, two magazines that provided platforms for debates about inequality in Cuba, the government's development strategy, and "the everyday life of the Cubansthe hopes, the expectations, their frustrations," as Orlando Marquez, Palabra Nueva's long-time editor remarked in 2013 (Márquez Hidalgo 2013: 6).

In January 2013, Espacio Laical published a symposium on the media in Cuba, calling for it to broaden itself and to democratize decision-making about what is published. Production of that issue stimulated the editors, Roberto Veiga González and Lenier González Mederos, to resign from the magazine in 2014 in order to create Cuba Posible - an ambitious project independent of the Church. Cuba Posible organizes public forums, publishes a range of blogs on line, and tries to facilitate cooperative research among its growing network of members. It has acquired an international audience, and the founders' aspiration is that it will become a broad platform for the discussion of Cuba's problems and alternate solutions (Brenner and Eisner 2018: 341).

Despite of these advances, there were constraints on free political expression in Cuba. The United Nations Educational, Scientific and Cultural Organization (UNESCO) noted reports of intimidation and arrests of journalists working for non-state run digital media. At the same time, Cuba did not have a freedom of information law and media law, which leaves independent journalists and filmmakers without a regulatory framework of protections/rights and responsibilities/duties. Defamation remained criminalized and those who 
produced or circulated publications without indicating the origin or in noncompliance with the rules relating to publication could face imprisonment for up to one year and/or a fine (Human Rights Council 2018).

Part of Cuba's "siege mentality" can be explained in terms of national security concerns and its relations with the United States. Cuba has been vulnerable to cyberattacks which have been used to spread lies and to attempt the creation of networks capable of fomenting "spontaneous" actions against the government. For example, USAID's so-called “democracy promotion" programs included a Twitter-like effort named ZunZuneo that enrolled about forty thousand unsuspecting Cubans in a plan to incite the kind of flash mobs that were prominent during the Arab Spring (Sanger 2014). In June 2017, President Trump signed a National Security Presidential Memorandum creating a Cuba Internet Taskforce to examine "the opportunities for expanding Internet access and freedom of expression in Cuba" (U.S. Department of State 2017).

\section{SHIFTING FOREIGN POLICY}

When Cuba and the United States re-established normal diplomatic relations in 2015 , both countries recognized that the normalization of all their relations would be a process likely to take many years. While they previously had diplomatic relations, they never had a normal relationship to which they could return: not when Cuba was a Spanish colony; not during the 1898 to 1903 occupation; not during the 1903 to 1933 period when the Platt Amendment was in force; not during the Good Neighbor period when U.S. companies controlled the Cuban economy; not during the Batista years; and certainly not during the period of hostility after 1959. The two countries needed to draw a new map if they were going to travel the road from normal diplomatic relations to normal relations.

As the two governments sought to make the movement toward relations "irreversible" in 2015 and 2016, they engaged in a flurry of activity and produced several agreements. Negotiations cut across a range of issues that the two countries had not previously discussed, including environmental cooperation, law enforcement, combating trafficking in persons, and property claims. Regularly scheduled airline service, direct postal services, advanced telecommunications connections, and new avenues for commerce were made possible when the United States relaxed some sanctions and the State Department removed Cuba from its list of state sponsors of terrorism. Cuba and the United States also established a bilateral commission to serve as "the primary coordination vehicle for advancing the normalization process" (U.S. Department of State 2015).

President Barack Obama traveled to Havana in March 2016. Accompanied by his family and a large contingent of U.S. senators and representatives, the U.S. leader was cheered by throngs of Cubans as he went from one meeting to another, toured Old Havana, and attended a baseball game. Hours before his 
arrival, Cuban and U.S. representatives signed agreements for the two countries to work together on maritime safety and research on sustainable agricultural development. Several other agreements followed, including one on health research that led to new Treasury Department rules allowing U.S. citizens to engage in joint medical research projects with Cuban nationals and that permit imports of Cuban-origin pharmaceuticals. Shortly afterwards, the Roswell Park Cancer Institute in Buffalo, New York, began clinical trials on a Cuban drug, Cimavax, that may pave the way to developing a lung cancer vaccine.

Republican presidential candidate Donald Trump derided these efforts to normalize US-Cuban relations during the campaign and noted correctly that as president he would have the authority to reverse nearly all of President Obama's initiatives. Yet in 2017 he allowed discussions to continue on most of the issues over which U.S. and Cuban officials had been meeting in 2016. Moreover, he formally tightened only one of the sanctions President Obama had relaxed and then added a new one. Under the first change, the Treasury Department reimposed a requirement that U.S. citizens could travel to Cuba for educational purposes only with a licensed travel provider. The second regulation banned any commerce with a Cuban entity owned or controlled by the military, which placed many hotels, restaurants and stores off limits to Americans.

Far more significant in slowing the movement toward normalization was President Trump's hostile rhetoric, and a decision to label a series of illnesses experienced by 24 U.S. embassy personnel as "sonic attacks," for which he asserted Cuba should bear responsibility. The illnesses, which in the most severe cases mimicked the kind of concussion that occurs from a physical blow to the head, occurred over a period of several months in late 2016 and 2017. A study published in the Journal of the American Medical Association reported that three or four people in the group had persistent cognitive, balance, auditory or visual impairment more than three months after initially experiencing a problem. The study concluded that the illnesses may have been due to a "novel mechanism... from a directional exposure of undetermined etiology" (Swanson et al. 2018). Despite the uncertainty about the cause of the problems, and with no evidence that Cuba had caused or had taken insufficient action to prevent the harm, the Trump administration evacuated most of the Embassy staff from the country and designated Cuba as an unaccompanied post. It then demanded that Cuba reduce the size of its embassy staff in Washington. The consequences were that several U.S. organizations cancelled planned educational trips to the island, and Cubans seeking a visa for travel to the United States had to travel to a third country to obtain one.

Cuba's relations with the rest of the hemisphere fared much better in 2017, despite the rise to power of conservatives in countries such as Brazil and Argentina, and the turmoil in Venezuela that has vitiated its influence in the region. Cuban medical personnel continued to work on contract throughout the hemisphere, and in 2016 and 2017 presidents from Peru, Colombia and Canada visited Cuba. 
In a significant departure from past policy, in 2017 Cuba received representatives of the United Nations Human Rights Council (UNHCR) and United Nations Special Rapporteur on trafficking in persons for meetings. These visits at the invitation of the island's authorities marked a new stage in relations between the UN and Cuba, which had not received any independent expert from the UNHCR in the prior 10 years.

This came shortly after Cuba and the European Union began holding highlevel discussions on human rights, which have covered issues of freedom of association, civil society engagement, gender and racial discrimination, and the treatment of vulnerable groups, migrants, refugees and asylum seekers. In 2017, the European Union Parliament followed up these meetings by approving a Political Dialogue and Cooperation Agreement with Cuba which dissolved the previous EU Common Position toward Cuba that had imposed sanctions on the island. The Agreement signaled each party's intent to normalize relations, expand bilateral trade, promote dialogue and economic cooperation, and develop plans for joint actions in multilateral fora (European Union External Action 2016). In addition, the European Union's top diplomat, Federica Mogherini, visited Cuba in January 2018 to help strengthen member countries' economic and political ties with the island.

Cuba's role as guarantor, along with Norway, in the Colombia peace process contributed to its high standing in the region. Described as "the perfect host" by several members of Colombia's government team, and the "unsung stars of the peace process" by a diplomat who was very familiar with it, Cuba hosted the negotiations and various meetings with advisers, envoys, and diplomats at the Cuban embassy in Bogotá and in Havana (Segura and Mechoulan 2017: 12). Cuba also contributed to the settlement by offering one thousand medical school scholarships to Colombians (AP 2017).

Linkages between Cuba and China extended beyond the increased economic ties noted earlier. For example, in 2017, there were meetings in Havana between the All-China Federation of Trade Unions and the Confederation of Cuban Workers. Subsequently, a delegation of Cuban parliamentarians toured several Chinese provinces. Chinese culture-reflected in the celebration Chinese Spring Festivals, the creation of several Confucius Institutes, and martial arts exhibitions-has also become an integral part of Cubans' daily life. The 2018 Havana Book Fair was dedicated to China as the guest country.

\section{CHANGING SOCIAL RELATIONS}

The Cuban government does not gather data on income distribution. Yet, increasing inequality is evident in the clothing Cubans wear, their choices in transportation and communication, the quality of their housing, and their differential abilities to enjoy restaurants and recreation available only to those with a surplus of hard currency. Anthropologist Hope Bastian reports that 
inequality has not only created gaps in consumption. It has altered social relations, as local community ties have begun to disintegrate generating new patterns of social stratification, and it has changed Cubans' values with a greater emphasis on materialism and individualism (Bastian 2018). These changes have not been managed well by Cuban political leaders, especially the Communist Party, and are a source of pressure for economic and political change that the new president will feel immediately.

Moreover, economic inequality has emerged "along clearly visible racial lines," as sociologist Katrin Hansing observes (2017: 331). A greater proportion of darker-skinned than lighter-skinned Cubans live in substandard housing which is unsuitable for Airbnb rentals, lack access to capital from remittances, and suffer discrimination due to racist norms in hiring for the tourism industry. They are also more poorly placed to take advantage of openings in the private sector. As a result, anti-racism organizations have re-emerged across the island in the last decade, focusing on fields from legal rights to youth, culture, communications, and barrio-based community organizing (Fernandes 2016).

In May 2017, a transgender pastor held a mass in Matanzas city for the first time. It reflected the change in homophobic attitudes that has occurred in Cuba over the last decade (Marsh and Rios 2017). Educational campaigns on LGBT issues have been spearheaded by the National Center for Sex Education, headed by Mariela Castro Espín, a member of the Cuban Parliament and President Raúl Castro's daughter. She has led Pride parades in Havana every May since 2008, to coincide with the International Day Against Homophobia. In addition, since 2008, doctors have been conducting state-funded sexual reassignment surgery. Notably, in 2010, Fidel Castro acknowledged the injustice in the mid1960s of sending thousands of gay men and others deemed unfit for military service to labor camps known as Military Units to Aid Production and accepted responsibility for the policy (Smith 2018).

Cuba's constitution defines marriage as "the voluntary established union between a man and a woman." Neither marriages nor civil union ceremonies of gay partners are legal in Cuba, although a campaign for same-sex marriageNosotros También Amamos (We Also Love) — has gained strength (Lavers 2016). While adoption by same-sex couples is not legally recognized, in January 2018, a three-judge panel broke new ground in granting a Cuban woman and her same-sex partner custody of the woman's grandchildren (Lavers 2018).

Two of the biggest challenges that Cuban society faces are is its aging population and emigration. Nearly one-fifth of the population $(19.8 \%)$ is over sixty years of age. If its current pace is maintained, Cuba will have the oldest population in Latin America and the ninth oldest population in the world by 2050 (ONEI 2017a: 23). The aging of Cuba's population is due partly to the country's fertility rate of only 1.7 births per woman, one of the lowest in the Western Hemisphere (IndexMundi 2017). Several factors account for this rate. A combination of widespread preventive and advanced curative medical care has raised life 
expectancy for the average Cuban to 79.6 years (United Nations Development Program 2015). Cuba's health-care system also makes contraceptives widely accessible and abortions are available on demand. At the same time, Cuban women are a growing portion of the country's professional workforce and many choose to delay motherhood until their late 30 s.

In an attempt to reverse its sagging birthrate and defuse a demographic time bomb, Cuba approved a decree giving parental leave to the grandparents of newborns (Puig Meneses 2017). Another decree reduced day-care costs for Cuban parents with multiple children and provided tax breaks for women who work in the country's non-state sector. The island already has one of the most generous parental leave policies in the Americas, allowing mothers and fathers to take more than a year off from work at partial pay.

An insufficient availability of professional jobs for educated Cubans, and the low pay for professionals, led younger people especially to emigrate permanently starting in the early 1990s, which also skewed the average age upward. The 2013 law that permits most Cubans to travel abroad for up to two years without losing property or citizenship rights may have stemmed the phenomenon of permanent emigration. But there is not enough post-2013 data available to determine if there has been a change.

\section{CONCLUDING OBSERVATIONS}

The end of an era does not always herald the arrival of a new one. While the change in Cuba's leadership certainly signifies the close of the Castro era, the nature of the era that will follow may not be clear for several years. In his first speech as the new president, Miguel Díaz-Canel emphasized that he would maintain current policies and goals rather than pursue change. He asserted, "I assume this responsibility with the conviction that all we revolutionaries, from any trench, will be faithful to Fidel and Raúl," adding that Raúl Castro, as first secretary of the Cuban Communist Party, "will take the lead on decisions of greatest importance for the present and future of the county" (Díaz-Canel Bermúdez 2018).

Yet the new Cuban leader was handed a portfolio of challenges-creating a sustainable developmental model that would maintain Cuba's egalitarian and communitarian values, establishing a single currency and encouraging foreign investment, strengthening partnerships with other countries while avoiding dependence on a single partner, stemming the discontent and emigration of Cuba' youth-that can be met only by change in the existing rules and institutions. Notably, three of the six Vice Presidents of the Council of State are new, and they range in age from 48 to 52 years. More than half of the members of the newly elected National Assembly that anointed Díaz-Canel as President were first-time deputies. Also, for the first time, its membership closely reflected 
the gender (53\% women) and racial ( $41 \%$ black and mulatto) composition of the country (Hernández 2018).

In short, during 2016 and 2017 Cuba attempted to close out the Castro era by making some headway in implementing the changes Raúl Castro had sought. But it fell short of fully addressing the problems Cubans and the Cuban leadership alike have identified, and it did not provide a clear trajectory for Cuba's new leaders to follow.

\section{REFERENCES}

AP. 2017, 16 March. "Cuba Offers Colombia 1,000 Medical School Scholarships." Associated Press. Accessed 20 April 2018. https://apnews.com/827ae08af1144c8688bcc3732f5e5a1f/cuba-offers-colombia-1000-medical-school-scholarships

Bastian, Hope. 2018. Adjusting to the Adjustment: Inequalities and Mobility in Everyday Life in Havana, Cuban Society after the Guidelines. Lanham, MD: Lexington.

Boadle, Anthony. 2006, 20 December. "Raul Castro Calls for More Policy Debate in Cuba." Washington Post. Accessed 2 April 2018. http://www.washingtonpost.com/wpdyn/content/article/2006/12/20/AR2006122001825_pf.html

Brenner, Philip, and Peter Eisner. 2018. Cuba Libre: A 500-Year Quest for Independence. Lanham, MD: Rowman and Littlefield.

Castro Ruz, Fidel. 1990, 28 January. "Discurso XVI Congreso de la CTC." Accessed 20 April 2018. http://www.cuba.cu/gobierno/discursos/1990/esp/f280190e.html

Castro Ruz, Raúl. 2010, 1 August. "Speech at the National Assembly August." Accessed 20 April 2018. http:/ / www.cuba.cu/gobierno/rauldiscursos/2010/esp/r010810e.html

Castro Ruz, Raúl. 2012, 12 January. "Speech by Army General Raúl Castro Ruz, President of the Councils of State and Ministers, closing the 1st National Conference of $\mathrm{Cu}$ ban Communist Party." Accessed 20 March 2018. http://www.minrex.gob.cu/en/ speech-army-general-raul-castro-ruz-president-councils-state-and-ministers-closing-1st-national

Castro Ruz, Raúl. 2016, 18 July. "The Revolutionary Cuban People will Again Rise to the Occasion, Speech to the closing session of the National Assembly." Accessed 29 February 2018. http://en.granma.cu/cuba/2016-07-13/the-revolutionary-cuban-people-will-again-rise-to-the-occasion

Castro Ruz, Raúl. 2017, 22 December. "We Are here, and Will Remain, Free, Sovereign and Independent." Accessed 20 April 2018. http://en.granma.cu/cuba/2017-12-22/weare-here-and-will-remain-free-sovereign-and-independent

Cuba Posible. 2018, 1 February. "Cartografía preliminar de los medios en Cuba: un mapa interactivo." Accessed 29 April 2018. https://cubaposible.com/cartografia-preliminar-los-medios-cuba-mapa-interactivo/

Communist Party of Cuba. 2016, 18 April. "Seventh Congress of the Communist Party of Cuba, Resolution on the Results of Implementing the Lineamientos." Accessed 20 April 2018. http://www.cubadebate.cu/especiales/2016/04/18/resolucion-sobre-resultados-de-la-implementacion-de-los-lineamientos-de-la-politica-economica-y-social-del-partido-y-la-revolucion-aprobados-en-el-vi-congreso-y-su-actualizacion-el-periodo-2016-2021

Díaz-Canel Bermúdez, Miguel. 2018, 19 April. "Speech to the National Assembly." Accessed 20 April 2018. http://www.granma.cu/elecciones-en-cuba-2017-2018/2018-04-20/ asumo-la-responsabilidad-con-la-conviccion-de-que-todos-los-revolucionarios-seremos-fieles-al-ejemplar-legado-de-fidel-y-raul-video-20-04-2018-04-04-02 
El Paquette. 2018, 11 April. "Listado del Paquete Semanal - Resumen de la semana version Omega 09-04-2018." Accessed 28 April 2018. http://paquetedecuba.com/listado-del-paquete-semanal-resumen-la-semana-version-omega-09-04-2018 /

Espina Prieto, Mayra. 2004. "Social Effects of Economic Adjustment: Equality, Inequality and Trends toward Greater Complexity in Cuban Society." In The Cuban Economy at the Start of the Twenty-First Century, edited by D. J. Eds, O. E. Pérez Villanueva, and L. Barbeira. Cambridge, MA: Harvard University Press: 209-243.

European Union External Action. 2016. "EU-Cuba Human Rights Dialogue in Havana." Accessed 20 April 2018. https://eeas.europa.eu/headquarters/headquarters-homepage/5024_en

Feinberg, Richard. 2018. "Cuba's Economy after Raul Castro: A Tale of Three Worlds.” Washington, DC: Foreign Policy at Brookings.

Fernandes, Sujartha. 2016, 24 May. "Afro-Cuban Activists Fight Racism Between Two Fires." The Nation. Accessed 20 March 2018. from https:/ / www.thenation.com/article/ afro-cuban-activists-fight-racism-between-two-fires /

Frank, Marc. 2017a, 18 April. "Cuba Warns of Further Belt Tightening as Venezuelan Crisis Deepens." Reuters. Accessed 20 January 2018. https://www.reuters.com/article/ cuba-economy / cuba-warns-of-further-belt-tightening-as-venezuelan-crisis-deepens-idUSL8N1I06XW

Frank, Marc. 2017b, 18 October. "Cash-strapped Cuba Makes Debt Payment to Major Creditors: Diplomats." Reuters. Accessed 20 April 2018. https://uk.reuters.com/article/ us-cuba-economy/cash-strapped-cuba-makes-debt-payment-to-major-creditors-diplomats-idUKKBN1CN2W3

Frank, Marc. 2017c, 31 October. “Cuba Reports Record \$2 Billion in Foreign Investment Deals." Reuters. Accessed 28 April 2018. https://www.reuters.com/article/us-cuba-investment/cuba-reports-record-2-billion-in-foreign-investment-deals-idUSKBN1D02NL

García Martínez, Antonio. 2017, 16 July. "Inside Cuba's DIY Internet Revolution." WIRED. Accessed 20 April 2018. https://www.wired.com/2017/07/inside-cubas-diy-internet-revolution/

Granma. 2017a, July. "Conceptualización del Modelo Económico y Social Cubano de Desarrollo Socialista." Accessed 20 April 2018. http://www.granma.cu/file/pdf/gaceta/ Conceptualización del modelo economico social Version Final.pdf

Granma. 2017b, 29 August. "Cuba Joins the Central American Bank for Economic Integration." Accessed 20 February 2018. http://en.granma.cu/cuba/2017-08-29/cuba-joins-the-central-american-bank-for-economic-integration

Granma. 2017c, 10 September. "AZCUBA: daños preliminares causados por Irma." Accessed 22 February 2018. http://www.granma.cu/cuba/2017-09-10/azcuba-danos-preliminares-causados-por-irma-10-09-2017-23-09-56

Granma. 2018, 19 April. "Minute to Minute: Continuity of the Revolution with a New Council of State in Cuba." Accessed 20 February 2018. http:/ / en.granma.cu/cuba/2018-04-19/ minute-to-minute-continuity-of-the-revolution-with-a-new-council-of-state-in-cuba

Hansing, Katrin. 2017. "Race and Inequality in the New Cuba: Reasons, Dynamics, and Manifestations" Social Research: An International Quarterly 84 (2): 331-349.

Harris, Johnny. 2015, 26 October. "Why Cuban Cab Drivers Earn More than Doctors." Accessed 20 February 2018. https://www.vox.com/2015/10/26/9593658/cuban-castro-taxi-driver-doctor-economy

Hernández, Rafael. 2017. "Intellectuals, Civil Society, and Political Power." Social Research: An International Quarterly 84 (2): 407-428.

Hernández, Rafael. 2018, 19 April. "Cuba probable. La transición socialista y el nuevo gobierno." Latin American Perspectives, Political Report \# 1332. Accessed 20 April 2018. https://laperspectives.blogspot.com/2018/04/exclusive-cuba-probable-la-transicion. html

Human Rights Council. 2018, 16 March. "Report of the Office of the United Nations High Commissioner for Human Rights. Compilation on Cuba." Accessed 19 May 2018. ht- 
tps:/ /documents-dds-ny.un.org/doc/UNDOC/GEN/G18/066/23/PDF/G1806623. pdf?OpenElement

IndexMundi. 2017. "Total Fertility Rate (Children Born/Woman)." Accessed 20 February 2018. https:/ / www.indexmundi.com/g/g.aspx?c=cu\&v=31

International Telecommunications Union. 2017. "Percentage of Individuals Using the Internet." Accessed 20 January 2018. https://www.itu.int/en/ITU-D/Statistics/Pages/ stat/default.aspx

Jervis, Rick. 2018 “Cuba, Once Bustling with Heavy-Spending Americans, Sees Steep Decline in U.S. Travelers." USA Today. Accessed 20 February 2018. https://www.usatoday. com/story/news/world/2018/04/07/cuba-visitors-travel-down-trump-policy-obama-castro-havana-cruise-ship/371612002/

Kemp, Simon. 2017, 24 January. “Digital in 2017: Global Overview." Accessed 20 January 2018. https://wearesocial.com/special-reports/digital-in-2017-global-overview

Lavers, Michael. 2016, 7 June. "Cuba Same-Sex Marriage Campaign Gains Traction." Accessed 23 February 2018. https://www.washingtonblade.com/2016/06/07/cuba-same-sex-marriage-campaign-traction/

Lavers, Michael. 2018, 25 January. "Cuban Woman with Same-Sex Partner Granted Custody of Daughter's Children." Accessed 24 February 2018. http:/ / www.washingtonblade. com/2018/01/25/cuban-woman-sex-partner-granted-custody-daughters-children/

Márquez Hidalgo, Orlando. 2013, 29 July. "The Role of the Catholic Church in Cuba Today." The Brookings Institution. Unedited transcript. Accessed 20 February 2018. https://www. brookings.edu/wp- content/uploads/2013/07/20130729_cuba_catholic_church_transcript. pdf

Marsh, Sarah., and Rios, Anett. 2017, 7 May. "Communist-Ruled Cuba Hosts First Transgender Mass." Reuters. Accessed 6 February 2018. https://www.reuters.com/article/ us-cuba-lgbt-church/communist-ruled-cuba-hosts-first-transgender-mass-idUSKBN1830EZ?il=0

Monreal Gonzalez, Pedro. 2017, 14 November. “Un Programa de Estabilidad Económica para Cuba." Accessed 2 February 2018. https://cubaposible.com/programa-estabilidad-economica-cuba/

Oficina Nacional de Estadisticas e Informacion (ONEI). 2017a. "Anuario Estadistico de Cuba. Capítulo 3: Poblacion." Accessed 2 February 2018. http://www.one.cu/aec2016/03 Poblacion.pdf

Oficina Nacional de Estadisticas e Informacion (ONEI). 2017b. "Capítulo 8: Sector Externo." Accessed 2 March 2018. http:/ / www.one.cu/aec2016/08 Sector Externo.pdf

Oficina Nacional de Estadisticas e Informacion (ONEI). 2018. “Organización institucional. Principales entidades." Octubre-Diciembre 2017. Accessed 2 March 2018. http:/ /www. onei.cu/ryc/organizacioninstitucional/OrgInst_1712.pdf

Partido Comunista de Cuba. 2016. “Conceptualización del Modelo Económico y Social Cubano de Desarrollo Socialista." Havana: Documento del VII Congreso del PCC.

Puig Meneses, Yaima. 2017, 9 February. "Estímulo a la natalidad: entre el desafío y lo posible." Accessed 25 March 2018. http://www.granma.cu/cuba/2017-02-09/estimulo-a-la-natalidad-entre-el-desafio-y-lo-posible-09-02-2017-23-02-14

Radio Rebelde. 2016, 2 September. "Firman primer acuerdo de colaboración Cuba y Banco de Desarrollo de América Latina." Accessed 2 March 2018. http:/ /www.cmhw.cu/ nacionales/2684-firman-primer-acuerdo-de-colaboracion-cuba-y-banco-de-desarrollo-de-america-latina?utm_source=twitterfeed\&utm_medium $=$ twitter

Reuters. 2018, 10 January. "Algeria Sends More Oil to Cuba as Venezuelan Supplies Fall." Accessed 2 March 2018. https://www.reuters.com/article/us-algeria-oil-cuba/algeria-sends-more-oil-to-cuba-as-venezuelan-supplies-fall-idUSKBN1EZ28O

Sanger, David. 2014, 4 April. "U.S. Says It Tried to Build a Social Media Site in Cuba, but Failed." New York Times. Accessed 2 May 2018. https://www.nytimes.com/2014/04/04/ world/americas/us-says-it-tried-to-build-a-social-media-site-in-cuba-but-failed.html 
Sánchez Egozcue, Jorge Mario. 2014. "Challenges of Economic Restructuring in Cuba." In A Contemporary Cuba Reader: The Revolution Under Raúl Castro, edited by Philip Brenner, Marguerite Rose Jiménez, John M. Kirk, William M. LeoGrande. Lanham, MD: Rowman and Littlefield, 125-138.

Segura, Renata, and Delphine Mechoulan. 2017, February. "Made in Havana: How Colombia and the FARC Decide to End the War." Accessed 27 March 2018. https:/ / www.ipinst. org/wp-content/uploads/2017/02/IPI-Rpt-Made-in-Havana.pdf

Smith, Lydia. 2018. "Inside Cuba's LGBT Revolution: How the Island's Attitudes to Sexuality and Gender Were Transformed." The Independent. 4 January. Accessed 2 March 2018. https://www.independent.co.uk/news/world/americas/cuba-lgbt-revolution-gay-lesbian-transgender-rights-havana-raul-castro-a8122591.html

Swanson, Randel, Stephen Hampton, and Judith Green-McKenzie. 2018. “Neurological Manifestations Among US Government Personnel Reporting Directional Audible and Sensory Phenomena in Havana, Cuba." Journal of the American Medical Association 319 (11): 1069-1176.

Torres Perez, Ricardo. 2017. "Updating the Cuban Economy: The First 10 Years." Social Research: An International Quarterly 84 (2): 255-275.

United Nations Development Program. 2015. "Human Development Indicators." Accessed 2 March 2018. http://hdr.undp.org/en/countries/profiles/CUB

U.S. Department of State. 2015, 10 November. "United States and Cuba Hold Second Bilateral Commission Meeting in Washington, D.C." Accessed 2 March 2018. https:/ /2009-2017. state.gov/r/pa/prs/ps/2015/11/249401.htm

U.S. Department of State. 2017, 20 October. "Strengthening the Policy of the United States Toward Cuba." National Security Presidential Memorandum NSPM-5. Accessed 2 March 2018. https:/ /www.federalregister.gov/documents/2017/10/20/2017-22928/ strengthening-the-policy-of-the-united-states-toward-cuba

Teresa García Castro is a Program Associate at WOLA where she provides research and support for the Drug Policy and the Andes program. Prior to joining WOLA, Teresa was a research assistant at American University and worked as a specialist in international relations at the Cuban Ministry of Culture promoting artistic and educational exchanges.

Philip Brenner is Professor of International Relations and History at American University, coauthor of Cuba Libre: A 500-Year Quest for Independence (Rowman and Littlefield, 2018), and co-editor of A Contemporary Cuba Reader: The Revolution Under Raúl Castro (Rowman and Littlefield, 2014). Email: pbrenne@american.edu 